\title{
Juvenile and small fish diversity in mangroves of different root types in the Labuhan Coastal Area, Bangkalan, Indonesia
}

\author{
FARID KAMAL MUZAKI", DIAN SAPTARINI, ACIB SETIA IBADAH \\ Marine Biodiversity and Conservation Research Group, Ecology Laboratory, Department of Biology, Faculty of Science, Institut Teknologi Sepuluh \\ Nopember. Jl. Arief Rahman Hakim - Surabaya 60111, East Java, Indonesia. Tel./Fax. +62-31-5963857, `email: rm_faridkm@bio.its.ac.id.
}

Manuscript received: 19 July 2018. Revision accepted: 7 May 2019.

\begin{abstract}
Muzaki FK, Saptarini D, Ibadah AC. 2019. Juvenile and small fish diversity in mangroves of different root types in the Labuhan Coastal Area, Bangkalan, Indonesia. Biodiversitas 20:1537-1543. The complexities of mangrove root types are well known to have effect on communities of fish including larval, juvenile and adult stages. This study aimed to access the difference on species composition and diversity of juvenile and small fish from mangrove area of different root types, especially in mangroves of the coastal area of Sepulu, Bangkalan which is a mangrove protection area. The samples were collected from November 2016 to June 2017 using modified centipede nets and scoop nets. Four types of sampling locations were used. Areas with pneumatophores (S), stilt roots (R), a combination of both types (C) and areas without mangroves (T). At least 32 species from 16 families of juvenile and small fish were identified. Families of fish with highest number of species were Gobiidae with 13 species, followed by Ambassidae, Mugilidae, Eleotridae and Siganidae with 2 species each. Fish species with highest abundance in all sampling sites and periods were Oryzias javanicus (F. Adrianichthyidae, 22.039\%), Ambassis kopsii (F. Ambassidae, 17.878\%), Liza vaigiensis (F. Mugilidae, 9.613\%), Am. buruensis (F. Ambassidae, 9.261\%), Terapon jarbua (F. Terapontidae, 7.562\%), L. subviridis (F. Mugilidae, 7.385\%) and Pseudogobius javanicus (F. Gobiidae, 7.385\%), respectively. Result of two-way Anova ( $\mathrm{p}=0.05)$ suggest that area with stilt roots $(\mathrm{R})$ which were dominated by mangrove Rhizophora have relatively higher abundance and species richness of juvenile and adult small fish. In addition, average Shannon-Weaner diversity index (H') value in areas with stilt roots was 2.031 and highest compared to the other sampling sites.
\end{abstract}

Keywords: Diversity, juvenile fish, mangrove root, Labuhan coastal area, small fish

\section{INTRODUCTION}

Mangrove forests represent a special coastal transition ecosystem that occurr only in the tropics and some subtropical regions (Kurniawan et al. 2014) and are generally restricted to the intertidal zone (Giesen et al. 2006). Mangroves are mostly characterized by several structural aspects such as complexity of roots with special functions (FAO 1994) and a canopy composed of branches and leaves. Because of their nature and position in the interphase between land and sea, mangroves provide habitat for both terrestrial and aquatic organism (Nagelkerken and Faunce 2008; Kurniawan et al. 2014). They shelter aquatic organism from their predators and provide them suitable microhabitat and plentiful supply of food (Nanjo et al. 2014). Mangroves are especially of key importance to fish as shelter and many habitat function, including feeding, breeding, spawning and nursery ground (Nagelkerken and Faunce 2008; Brander et al. 2012; Vaslet et al. 2012).

At least two hypotheses have been proposed to explain why mangroves are attractive to fishes. The predator refuge hypothesis stated that the structural complexity of mangrove roots provides excellent shelter from predators for juvenile and small fishes which migrate into vegetated areas of mangroves, particularly when the trees are inundated by water (Laegdsgaard et al. 2001; Morinière et al. 2004; Nagelkerken et al. 2010; Nanjo et al. 2014). The feeding hypothesis proposes that there is a greater abundance of food within mangroves due to high productivity and the abundance of associated benthic fauna (Laegdsgaard et al. 2001; Wang et al. 2009), and that this is the main reason for fish attraction.

Mangrove systems provide a diversity of habitats to juvenile fishes but this diversity in habitats has very rarely been studies (Hylkema et al. 2014). Most quantitative studies of juvenile and small fish have focused only on comparing the community structure in mangrove and nonmangrove areas (Thayer et al. 1987; Wang et al. 2009; MacDonald and Weis 2013). However, comparisons of fish use of mangrove with different types of roots remains lacking and difficult to obtain. This study aimed to fill the gap in the information on diversity of juvenile and small fish in mangrove with different types of roots, and focusses on the coastal area of Labuhan, Sepulu, Bangkalan, Madura. The mangrove in Labuhan is projected as mangrove conservation and education area. More than 12 species of true mangroves and 25 species of associate mangrove have been documented. These create horizontal habitat zonation that can be easily recognized by species differences as each species has different root types (Muzaki et al. 2017). Data obtained from this study can be used as baseline for mangrove management in the area, especially as a consideration in determining which species of mangrove will provide better fish habitat and may therefore be preferred to be planted in ecological rehabilitation efforts. 


\section{MATERIALS AND METHODS}

\section{Study area}

Four sampling sites or stations representing vegetated and non-vegetated areas were established, as shown in Figure 1. The R station was dominated by Rhizophora spp. with stilt roots, the $\mathrm{S}$ station was dominated by Sonneratia alba with pneumatophores, the $\mathrm{C}$ station had mixed species (including Rhizophora, Sonneratia, Avicennia and others) and mixed root types (stilt root and pneumatophore). while station $\mathrm{T}$ was a non-vegetated area (Figure 1).

\section{Specimen collection and processing}

Sample collections were conducted monthly from November 2016 to June 2017. The specimens were collected by a modified centipede net $(200 \times 60 \times 40 \mathrm{~cm}$ in dimension, $0.5 \mathrm{~cm}$ mesh size $)$ and scoop net $(0.5 \mathrm{~cm}$ mesh size). The centipede nets was placed at depth of 70-100 cm in small creeks in the proximity of the mangroves in same location and installed at high tide and then checked again at low tide ( \pm 4 hours after installation) (Wang et al. 2009). At each sampling site, three replicate samples were obtained.

In the laboratory, juvenile and small fish samples were sorted and separated and the number of individual of each species were counted. Identification to the level of species made use of the following sources: Allen and Steene (1994), Rainboth (1996), Carpenter and Niem (1998), Allen et al. (2000), Kuiter and Tonozuka (2001) and Peristiwady (2006). Ambient parameters measured in situ included salinity, water temperature, alkalinity or $\mathrm{pH}$, level of dissolved oxygen (DO), turbidity and abundance of plankton (phytoplankton and zooplankton).

Plankton samples were collected by plankton net with a mesh size of 0.063 (for phytoplankton) and $0.150 \mathrm{~mm}$ (for zooplankton). The net was towed subsurface in proximity of mangroves. The towing path was 100-meter-long and duplicate samples were obtained from each location (Muzaki et al. 2017). Collected plankton samples were immediately preserved in $10 \%$ buffered-formaldehyde for further analysis in the laboratory.

\section{Data analysis}

Two-way analysis of variance (Anova) (Wang et al. 2009; Ooi and Chong 2011), was followed by a Tukey's HSD test (both at $\mathrm{p}=0.05$ ) to compare the differences in fish abundance and species richness among locations and sampling periods. Species richness (S) was represented as the number of species in particular location and period; while diversity was expressed by the Shannon-Wiener index:

$$
H^{s}=-\sum\left[\frac{n_{i}}{n} \ln \left(\frac{n_{i}}{n}\right)\right]
$$

Where $H^{\prime}$ is the Shannon-Wiener diversity index; $n i$ is the number of specimens of species-i and $N$ is total the number of specimens in the sample (Dhahiyat et al. 2003). The value of $H^{\prime}$ is then used to express the level of diversity of the community following Estradivari et al. (2007), as shown in Table 1.

Table 1. Criteria of diversity

\begin{tabular}{ll}
\hline Criteria & Value of H' \\
\hline High diversity & $\mathrm{H}^{\prime}>3.00$ \\
Moderate diversity & $2.00 \leq \mathrm{H}^{\prime} \leq 3.00$ \\
Low diversity & $2.00<\mathrm{H}^{\prime}$ \\
\hline
\end{tabular}

Source: Dhahiyat et al. (2003); Estradivari et al. (2007)
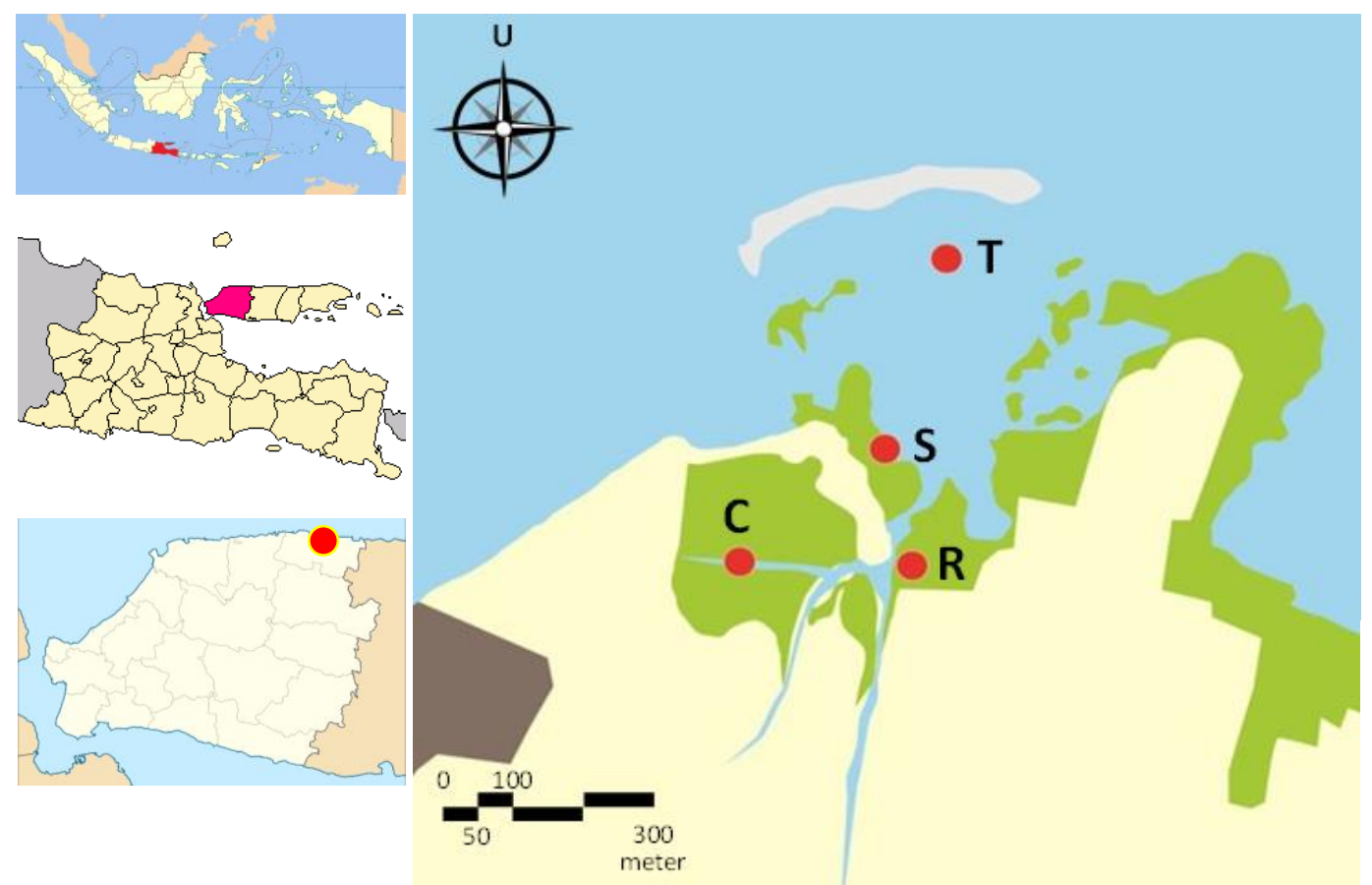

Legend:

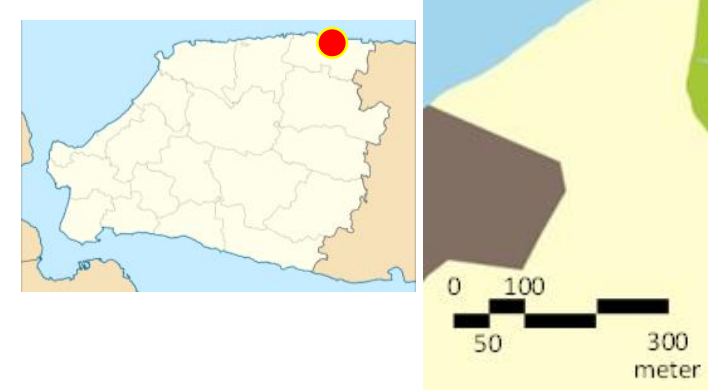

Figure 1. Juvenile and small fish sampling locations in coastal area of Labuhan, Sepulu, Bangkalan, Madura, Indonesia 
Table 2. Results of environmental variables measurement

\begin{tabular}{|c|c|c|c|c|c|c|c|}
\hline \multirow[t]{2}{*}{ Parameter } & \multicolumn{4}{|c|}{ Location } & \multirow[t]{2}{*}{ Quality standard } & \multirow{2}{*}{ OT } & \multirow{2}{*}{ Ref. } \\
\hline & $\boldsymbol{R}$ & $S$ & $T$ & $C$ & & & \\
\hline Salinity (\%o) & $28 \pm 7.62$ & $27.25 \pm 7.27$ & $25.75 \pm 6.7$ & $30 \pm 4.24$ & to 34 & $32.62 \pm 0.61$ & $\mathrm{P}$ \\
\hline Temperature $\left({ }^{0} \mathrm{C}\right)$ & $28.5 \pm 2.35$ & $28.7 \pm 2.11$ & $28.8 \pm 1.92$ & $29 \pm 2.65$ & $28-32$ & $29.50 \pm 1.92$ & $\mathrm{P}$ \\
\hline Turbidity (NTU) & $24.75 \pm 22.98$ & $42.63 \pm 27.91$ & $26.41 \pm 25.76$ & $26.78 \pm 12.59$ & $<5$ & $20.23 \pm 33.5$ & M \\
\hline Dissolved oxygen & $7.88 \pm 0.36$ & $7.74 \pm 0.36$ & $7.90 \pm 0.28$ & $7.44 \pm 1.34$ & $>5$ & $4.80 \pm 1.36$ & $\mathrm{P}$ \\
\hline $\mathrm{pH}$ & $7.56 \pm 0.92$ & $7.74 \pm 0.13$ & $7.78 \pm 0.18$ & $7.82 \pm 0.31$ & $7-8.5$ & $7.74 \pm 0.089$ & $\mathrm{P}$ \\
\hline Phytoplankton (cell/liter) & $6015.2 \pm 8653.2$ & $4483.4 \pm 3672.3$ & $2906.1 \pm 2847.5$ & $5084.9 \pm 5312$ & Not blooming & $1564.44 \pm 1042.88$ & $\mathrm{H}$ \\
\hline Zooplankton (ind./liter) & $942.7 \pm 872.3$ & $541.7 \pm 577.6$ & $343.7 \pm 264.8$ & $405.7 \pm 339.6$ & Not blooming & $1760 \pm 497.8$ & $\mathrm{H}$ \\
\hline Root density (unit/m²) & $128.4 \pm 34.44$ & $41 \pm 4.85$ & No roots & $105.6 \pm 10.1$ & NA & NA & \\
\hline
\end{tabular}

Note: Quality standard based on Appendix III of KepMen LH No 51 2004; NA: data not available; OT: compared to other author(s); H: Heriyanto (2012); P: Pribadi et. al. (2013); M: Muzaki et al. (2017)

\section{RESULTS AND DISCUSSION}

\section{Environmental variables}

The average value of environmental variables and quality standard for marine organism are available in Table 2. Based on Table 2, most of the environmental variables, except for turbidity, were still in range of quality standard for marine life, based on Ministry of Environment of Republic of Indonesia (2004). In detail, highest salinity was recorded only at November and December 2016 in station $\mathrm{R}$ and $\mathrm{T}$, with the value is $35 \%$. However, at January and February 2017, salinity and water temperature were lower, respectively, $\pm 23 \%$ and $\pm 26^{\circ} \mathrm{C}$; this is probably due to heavy rainfall prior the measurement of those variables. Most aquatic organism in the estuary were eurythermal and euryhaline species, therefore adapted to variable salinity and temperature (Jorgensen et al. 2013). Several species such as Mugilidae are able to withstand much higher salinities than observed in this study (Russel et al. 1970).

Turbidity in all sampling locations was higher than quality standard for marine organism (Ministry of Environment of Republic of Indonesia 2004). However, turbidity in estuary is usually high and can still be tolerated by many larval, juvenile and adult fish (Jorgensen et al. 2013; Muzaki et al. 2017). Higher turbidity in the estuary could be contributed to by decomposition of mangrove litter which releases tannins into the water (Setiawan 2013), wave action (Lamb et al. 2008), higher productivity and sediment inflow due to erosion from land.

Roots density was higher in $\mathrm{R}$ station compared to other stations, even in $\mathrm{C}$ station where the mangrove composed by Rhizophora, Sonneratia and Avicennia. This is probably caused by the age of the mangrove stands. In $\mathrm{C}$ station, the mangrove stands were smaller and younger than in $\mathrm{R}$ station therefore the density (per square meter) could be lower. This reason might also explain why the temperature in $\mathrm{C}$ station was higher than other locations. Older vegetation could mean denser shading and resulting in lower temperature under the canopy.

Plankton is one of food source for fish; and food availability is very important biotic factor in determining success of fish life cycle. Species composition and abundance of plankton may also affect fish production in their early life cycle (Kyewalyanga 2003). As a biotic component that is thought to be food source by juvenile and small fish, the abundance of phytoplankton and zooplankton in $\mathrm{R}$ station was higher while in $\mathrm{T}$ station was the lowest; therefore, it can be assumed that food source in $\mathrm{R}$ station is highest.

\section{Composition and abundance of juvenile and small fish}

After eight months of sampling from four stations, we identified 32 species of juvenile and small fish from 16 families. In station R, the of juvenile and small fish ranged from 37 specimens in November 2016 and 197 specimens in March 2017, whereas in station R 14 specimens were caught in November 2016 and 71 in June 2017. The abundance was lowest in November 2016 at the C and T stations, however highest abundance in both stations were recorded in June and February 2017, as shown in Figure 2.

The sampling area with the largest number of juvenile and small fish was station $\mathrm{R}$ with 932 specimens caught (50.437\% from total population), followed by station C with 506 specimens $(27.65 \%)$, station $S$ with 286 specimens $(15.628 \%)$, and station $\mathrm{T}$ with 115 specimens (6.284\%), respectively.

Result of two-way ANOVA and Tukey's HSD test (both with $p=0.05$ ) showed that the abundance of juvenile and small fish differed significantly among locations (Figure 4) with station R showing the highest abundance. Fish abundances appeared to be grouped into four distinct groups, in term of sampling period; namely NovemberDecember 2016, January to March 2017, April-May 2017 and June 2017 (Figure 5).

In general, at each sampling period, station $\mathrm{R}$ had the highest abundance of juvenile and small fish, followed sequentially by stations $\mathrm{C}$, and $\mathrm{T}$. This finding is consistent with several other studies that stated that vegetated coastal habitats support higher abundance of fish compared to nonvegetated habitat (Jenkins and Wheatley 1998; Jaafar et al. 2004; Nagelkerken and Velde 2004).

The most abundant species from November 2016 to June 2016 were Oryzias javanicus (F. Adrianichthyidae) amounting to $22 \%$ of all fish; followed by Ambassis kopsii (F. Ambassidae, 18\%), Liza vaigiensis (F. Mugilidae, 10\%), Terapon jarbua (F. Terapontidae, 8\%) and Pseudogobius javanicus (F. Gobiidae) and L. Viridis, both with $7 \%$, respectively. Individuals of $O$. javanicus were most often caught in $\mathrm{R}$ and $\mathrm{C}$ stations. 


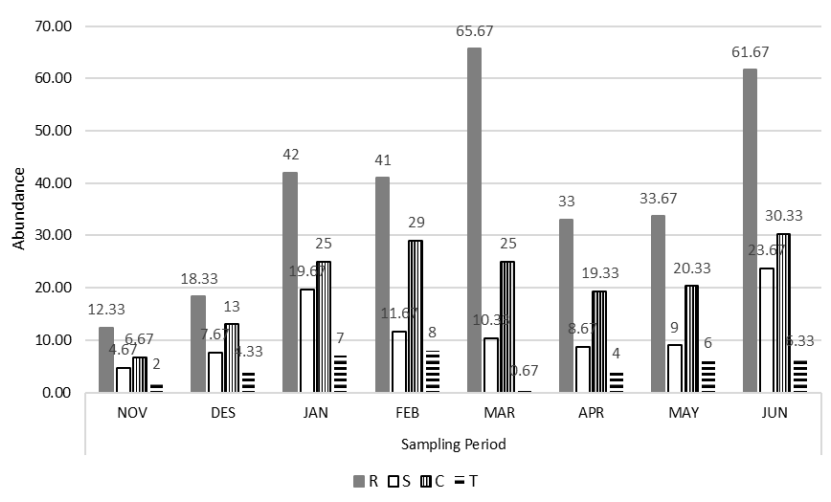

Figure 2. Average of abundance of juvenile and small fish in study area from November 2016 to June 2017

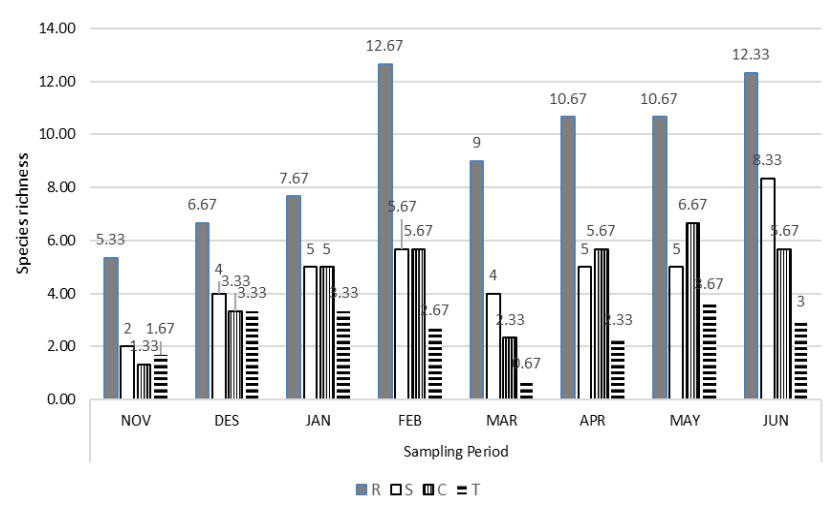

Figure 3. Average of species richness of juvenile and small fish in study area from November 2016 to June 2017

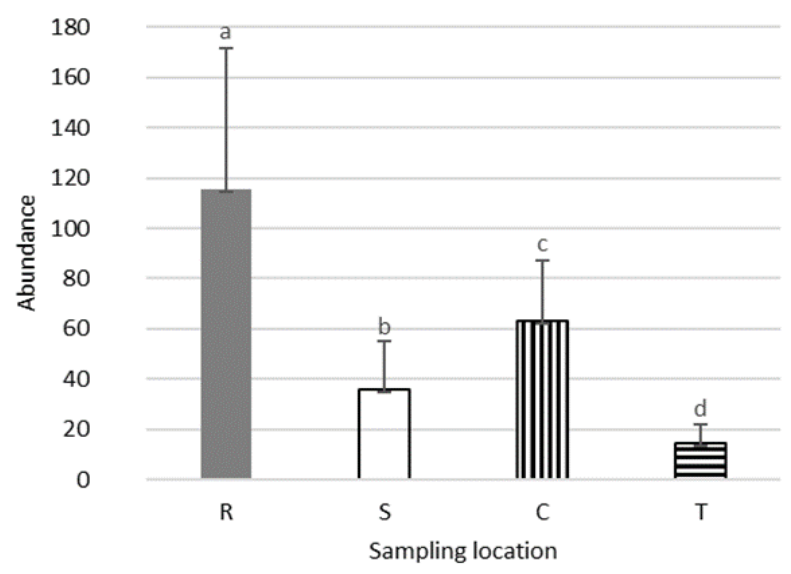

Figure 4. Result of Two-way ANOVA followed by Tukey HSD test $(\mathrm{p}=0.05)$ comparing abundance of juvenile and small fish among sampling locations; the bar with same alphabet symbol indicate no significant difference

The most numerically abundant family represented was the Ambassidae (27.\%, followed by the Mugilidae (17\%), Gobiidae $(15 \%)$ and Siganidae (3.\%). In studies by Tse et al. (2008) and Sichum et al. (2013) in mangroves and muddy areas of Hongkong and Thailand, respectively, Ambassidae were also the family with highest abundance. Nearshore estuarine areas are a key habitat of Ambassids that school in groups during the day and forage for food in the night (Carpenter and Niem 1998) and usually prefer sheltered areas (Shao and Chen 2003).

In this study, Gobiidae were also found in high abundance and also with high species richness. These findings were also consistent with results of studies by Wang et al. (2009) in Dongzhaigang Bay, Hainan Island and Sichum et al. (2013) where Gobiidae were also recorded as fish family with a high number of species and high individual abundance of each species.

\section{Species richness}

Lowest average of species richness in station $T$ occurred in March 2017 and highest species richness occurred in May 2017. For the other three stations (R, S and $\mathrm{C}$ ), lowest species richness was detected in November 2016 but the highest species richness was recorded in February, June and May 2017, respectively (Figure 3). Figure 7 and Figure 8 show the result of ANOVA and Tukey's HSD test $(p=0.05)$ for species richness among sampling stations and periods. There was significant difference in species richness among sampling stations but not among sampling periods, especially for December 2016 to June 2017.

Station $\mathrm{R}$ also had the highest species richness of juveniles and small fish compared to stations $\mathrm{C}, \mathrm{S}$ and $\mathrm{T}$. Highest species richness from all sampling locations was recorded in February 2017 and the lowest in November 2016 and March 2017. Fish abundance these habitats and the greater region is usually higher in the rainy season compared to dry season (Robertson and Duke 1990, Stoner 1986). The rainy season is a period where the abundance of juvenile fish and zooplankton are very high (Robertson and Duke 1990). Seasonal changes and changes in fish abundance over a given period may also be affected by the fish movements in response to reproduction and changes in food availability in the estuary (Ikejima et al. 2003).

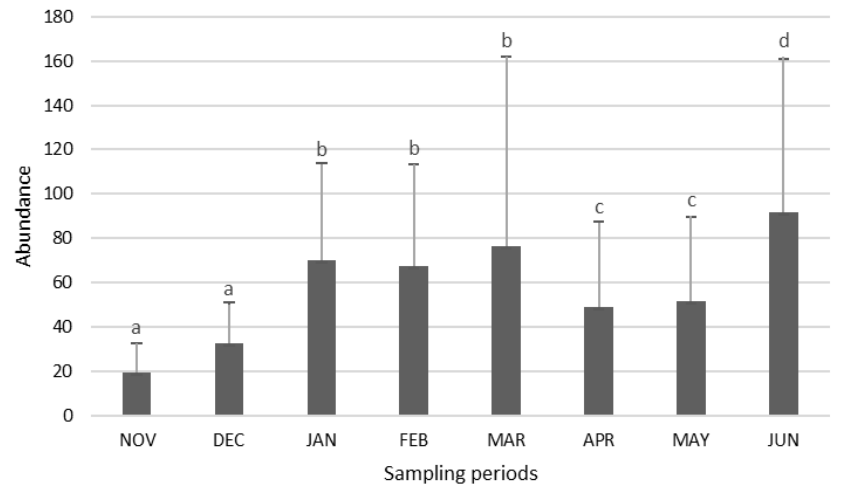

Figure 5. Result of Two-way ANOVA followed by Tukey HSD test $(p=0.05)$ comparing abundance of juvenile and small fish among sampling periods; the bar with same alphabet symbol indicate no significant difference 

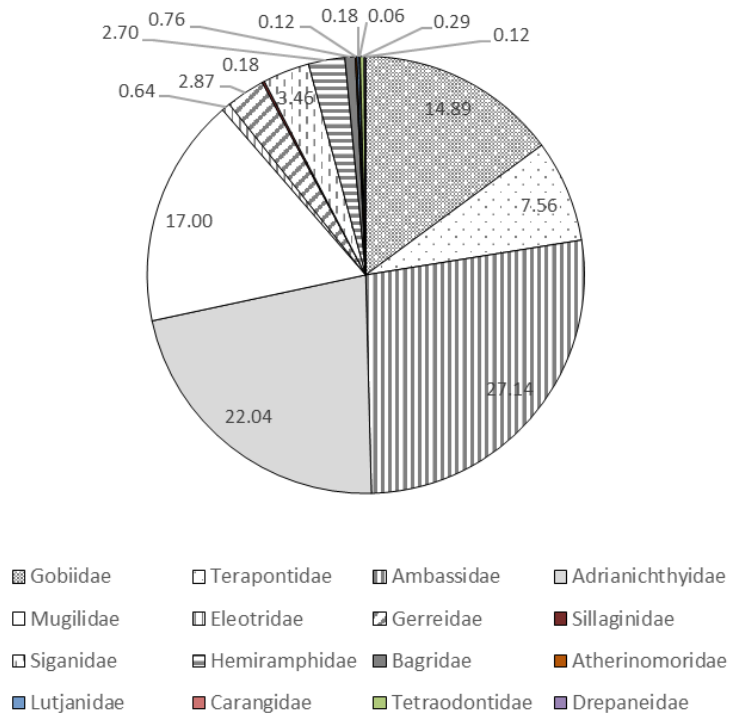

Figure 6. Percent of abundance of juvenile and small fish based on level of families in study area from November 2016 to June 2017

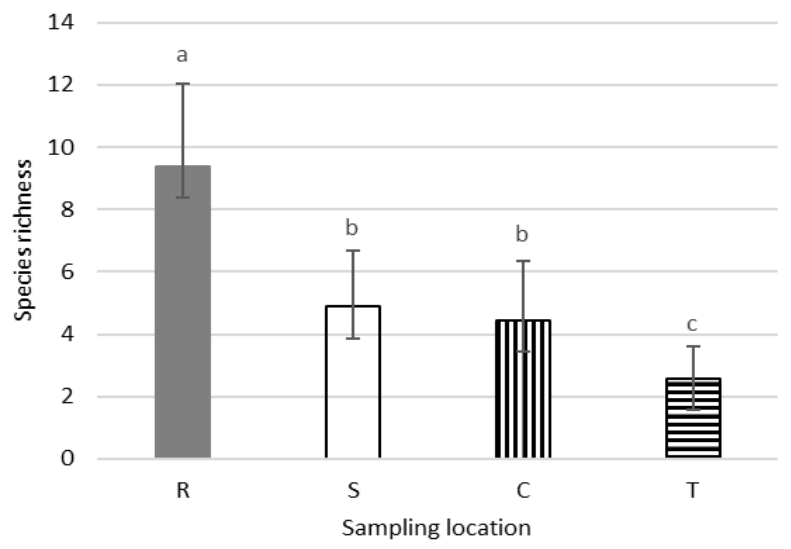

Figure 7. Result of Two-way ANOVA followed by Tukey HSD test $(p=0.05)$ comparing species richness of juvenile and small fish among sampling locations; the bar with same alphabet symbol indicate no significant difference

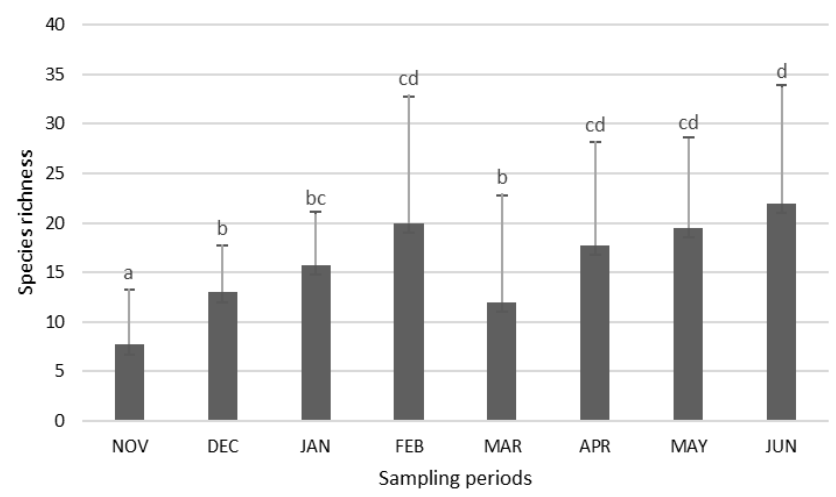

Figure 8. Result of Two-way ANOVA followed by Tukey HSD test $(p=0.05)$ comparing species richness of juvenile and small fish among sampling periods; the bar with same alphabet symbol indicate no significant difference

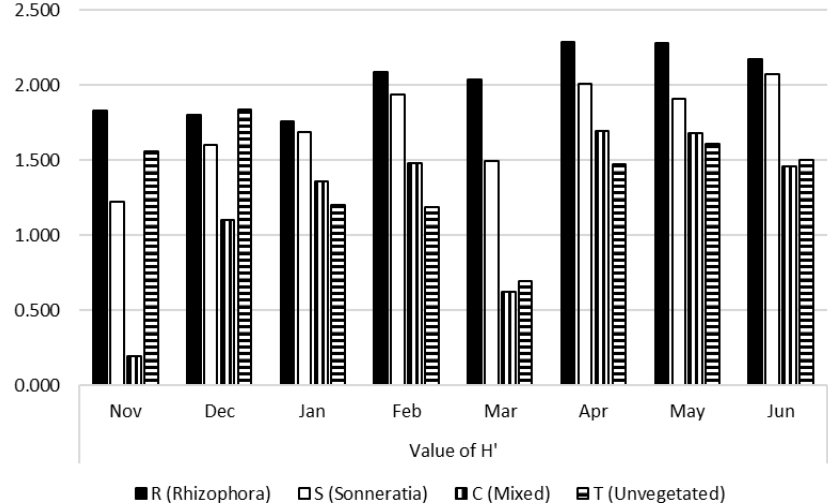

Figure 9. Value of Shannon-Wiener Diversity Index (H') of juvenile and small fish community in study area from November 2016 to June 2017

The function of vegetated habitats in coastal areas is as a nursery ground for juveniles (Nagelkerken et al. 2000), food sources (Chong et al. 1990; Hajisamae et al. 1999; Paterson and Whitfield 2000), and as a shelter (Bower et al. 1998) for juveniles. Vegetated areas may be of value to the juvenile stages of fish and small fish as these may help avoid predation. The habitat complexity of the roots, branches, and leaves structures provided by mangrove vegetation can shelter juvenile and small fish from predators (Laegdsgaard and Johnson 2001) . In addition, the complex root structure of mangroves can harbour epibionts that can be a source of food for small fish and small juveniles (Wang et al. 2009). MacDonald and Weis (2013) stated that the abundance of epibionts on the root surface of mangroves is positively correlated with the abundance of fish in the area.

\section{Shannon-Wiener Diversity Index}

The value of $\mathrm{H}^{\prime}$ in station $\mathrm{R}$ station ranged from 1.758 (January 2017) to 2.286 (April 2017), in station S from 1.220 (November 2016) to 2.074 (June 2017); in station C from 0.199 (November 2016) to 1.697 (April 2017) and in station $\mathrm{T}$ from 0.693 (March 2017) to 1.839 (December 2016) (Figure 9).

The higher value of $\mathrm{H}^{\prime}$ in station $\mathrm{R}$ is caused by highest number of species and more even abundance among species. In addition, station $\mathrm{R}$ station was dominated by Rhizophora mangroves with relatively higher root complexity and a denser canopy. Nagelkerken et al. (2010) found that fish abundance and diversity was generally higher in locations with higher root density and complexity and denser shading.

The lower diversity values in stations $\mathrm{S}$ and $\mathrm{C}$ appear caused by lower number of species and dominance of one or several species in those locations (Setiawan 2013). For example, $O$. javanicus is quite dominant in station $\mathrm{C}$ station; the species has averaged relative abundance of $38.199 \%$ from total population of fish in the area.

Species diversity likely contributes to the stability of the community; therefore stable communities will also often have high values of species diversity (Bower 1998). In 
general, the value of $\mathrm{H}^{\prime}$ documented in the fish communities we studied in our area were considered low $\left(H^{\prime}<2.00\right)$ and/or moderate $\left(2 \leq H^{\prime} \leq 3\right)$.

Based on our results we conclude that, the station with Rhizophora vegetation had the highest abundance and species richness of juvenile and small fish. We suggest that this is caused by more complex root systems and denser shading provided by Rhizophora species. As has been demonstrated elsewhere in general, in our study vegetated (mangrove) sampling areas also had relatively higher abundance and species richness compared to non-vegetated area.

In contrast to most other studies that have only examined mangrove habitat as a single category, this work shows that fish use of different habitats in a mangrove area, may differ greatly. Only by conducting more detailed studies can true insight be generated on how different fish species use mangrove areas in the different stages of their life cycle (de la Moriniere et al 2002; Hylkema et al. 2014).

\section{ACKNOWLEDGEMENTS}

We thank to Center of Research and Community Service (LPPM), Institut Teknologi Sepuluh Nopember, Surabaya, Indonesia for funding this research.

\section{REFERENCES}

Allen GR, Steene R. 1994. Indo-Pacific Coral Reef Field Guide. Tropical Reef Research, Singapore.

Allen GR, Swainston R, Ruse J. 2000. Marine Fishes of South-East Asia. Periplus Edition (HK) Ltd., Singapore.

Blaber SJM. 1997. Fish and Fisheries of Tropical Estuaries. Chapman \& Hall, London.

Bower JE. 1998. Field and Laboratory Methods for General Ecology. McGram-Hill Companies, USA.

Brander M, Wagtendonk AJ, Hussain SS, McVittie A, Verburg PH, Groo RS, Ploeg S. 2012. Ecosystem service values for mangroves in Southeast Asia: A meta-analysis and value transfer application. Ecosyst Serv 1: 62-69.

Carpenter KE, Niem VH (Eds). 1998. The Living Marine Resources of the Western Central Pacific. FAO Species Identification Guide for Fisheries Purposes. Food and Agricultural Organization of The United Nations, Rome.

Chong VC, Sasekumar A, Leh MUC, D’Cruz R. 1990. The fish and prawn communities of a Malaysian coastal mangrove system, with comparisons to adjacent mud flats and inshore waters. Estuar Coas Shelf Sci 31: 703-722.

De La Moriniere, EC, Pollux BJA, Nagelkerken I, Van der Velde G. 2002. Post-settlement life cycle migration patterns and habitat preference of coral reef fish that use seagrass and mangrove habitats as nurseries. Estuar Coast Shelf Sci 55(2): 309-321.

Dhahiyat Y, Sinuhaji D, Hamdani H. 2003. Struktur komunitas ikan karang di daerah transplantasi karang Pulau Pari, Kepulauan Seribu. Jurnal Iktiologi Indonesia 3 (2): 87-94. [Indonesian]

Estradivari, Syahrir M, Susilo N, Yusri S, Timotius S. 2007. Terumbu Karang Jakarta. Yayasan Terangi, Jakarta. [Indonesian]

FAO. 1994. Mangrove Forest Management Guidelines, FAO Forestry Paper 117. Food and Agricultural Organization of The United Nations, Rome.

Giesen W, Wulffraat S, Zieren M, Scholten L. 2006. Mangrove Guidebook for Southeast Asia. FAO and Wetlands International, Bangkok.

Hajisamae S, Yeeshin P, Ibrahim S, Sirimontaporn P. 1999. Abundance and diversity of juvenile fishes in Saiburi Estuary, Gulf of Thailand. Songklanakarin J Sci Technol 21: 265-275.
Heriyanto NM. 2012. Keragaman plankton dan kualitas perairan di hutan mangrove. Buletin Plasma Nutfah 18 (1): 38-44. [Indonesian]

Hylkema A., Vogelaar W, Meesters HWG, Nagelkerken I, Debrot AO. 2014. Fish species utilization of contrasting habitats distributed along an ocean-to-land environmental gradient in a tropical mangrove and seagrass lagoon. Estuar Coasts. DOI 10.1007/s12237-014-9907-1

Ikejima K, Tongnunui P, Medej T, Taniuci T. 2003. Juvenile and small fishes in mangrove estuary in Trang Province, Thailand: seasonal and habitat differences. Estuar Coast Shelf Sci 56: 447-457.

Jaafar Z, Hajisamae S, Chou LM., Yatiman Y. 2004. Community structure of coastal fishes in relation to heavily impacted human modified habitats. Hydrobiologia 511: 113-123.

Jenkins GP, Wheatley MJ. The Influence of habitat structure on nearshore fish assemblages in a Southern Australian Embayment: Comparison of shallow seagrass, reef-algal and unvegetated sand habitats, with emphasis on their importance to recruitment. J Exp Mar Biol Ecol 221: $147-172$.

Jorgensen S, Tundisi JG, Tundisi TM. 2013. Handbook of Inand Aquatic Ecosystem Management. CRC Press, Boca Raton.

Kuiter R.H, Tonozuka T. 2001. Pictorial Guide to Indonesian Reef Fishes. Part I - III. Zoonetics, Australia.

Kurniawan A, Hasan GMJ, Ooi SK, Kit LW, Loh LL, Bayen S. 2014. Understanding hydrodynamic flow characteristics in a model mangrove ecosystem in Singapore. APCBEE Procedia 10: 286-291.

Kyewalyanga MS. 2003. Assessment of types and abundance of live food for fish farming in Makoba Earthen Ponds, Zanzibar, Tanzania, Western Indian Ocean. J Mar Sci 2 (1): 45-56.

Laegdsgaard P, Johnson C. 2001. Why do juvenile fish utilize mangrove habitats? J Exp Mar Biol Ecol 257: 229-253.

Lamb MP, Myrow PM, Lukens C, Houck K, Strauss J. 2008. Deposits from wave-influenced turbidity currents: Pennsylvanian Minturn Formation, Colorado, U.S.A. J Sedimen Res 78 (1): 1-19.

MacDonald JA, Weis JS. 2013 Fish community features correlate with prop root epibionts in Caribbean mangroves. J Exp Mar Biol Ecol 441: 90-98.

Ministry of Environment of Republic of Indonesia, Resolution no 51 year 2004, Appendix III.

Morinière ECDL, Nagelkerken I, van der Meij H, van der Velde G. 2004. What attracts coral reef fish to mangroves? Habitat complexity or shade? Mar Biol 144: 139-144.

Muzaki FK, Giffari A, Saptarini D. 2017. Community structure of fish larvae in mangroves with different root types in Labuhan coastal area, Sepulu - Madura. AIP Conference Proceedings of $3^{\text {rd }}$ International Biology Conference (IBOC). Institut Teknologi Sepuluh Nopember, Surabaya, 10 October 2016. [Indonesian]

Nagelkerken I, De Schryver AM, Verweij MC, Dahdouh-Guebas F, van der Velde G, Koedam K. 2010. Differences in root architecture influence attraction of fishes to mangroves: A field experiment mimicking roots of different length, orientation, and complexity. J Exp Mar Biol Ecol 396: 27-34.

Nagelkerken I, Faunce CH. 2008. What makes mangroves attractive to fish? Use of artificial units to test the influence of water depth, crossshelf location, and presence of root structure. Estuar Coast Shelf Sci 79: 559-565.

Nagelkerken I, Velde GVD, Gorissen MW, Meijer GI, Van’t Hof T, den Hartog C. 2000. Importance of mangroves, seagrass beds and the shallow coral reef as a nursery for important coral reef fishes, using a visual census technique. Estuar Coast Shelf Sci 51: 31-44.

Nagelkerken I, Velde GVD. 2004. A comparison of fish communities of subtidal seagrass beds and sandy seabeds in 13 marine embayments of a Caribbean Island, based on species, families, size distribution and functional groups. J Sea Res 52: 127-147.

Nanjo K, Kohno H, Nakamura Y, Horinouchi M, Sano M. 2014. Effect of mangrove structure on fish distribution patterns and predation risks. $\mathrm{J}$ Exp Mar Biol Ecol 461: 216-225.

Ooi L, Chong VC. 2011. Larval fish assemblages in a tropical mangrove estuary and adjacent coastal waters: Offshore-inshore flux of marine and estuarine species. Continent Shelf Res 31: 1599-1610.

Paterson AW, Whitfield AK. 2000. Do shallow-water habitats function as refugia for juvenile fishes? Estuarine, Coastal and Shelf Science 51: 359-364.

Peristiwady T. 2006. Ikan-ikan Laut Ekonomis Penting di Indonesia: Petunjuk Identifikasi. LIPI Press, Jakarta. [Indonesian]

Pribadi R, Endrawati H, Pratikto I. 2013. Komunitas ikan di perairan kawasan Pulau Parang, Kepulauan Karimunjawa, Jepara. Ilmu Kelautan 18 (1): 45-53. [Indonesian] 
Rainboth WJ. 1996. Fishes of the Cambodian Mekong. Food and Agriculture Organization of the United Nations, Rome.

Robertson AI, Duke NC. 1990. Recruitment, growth and residence time of fishes in a tropical Australian mangrove system. Estuar Coast Shelf Sci 31: 723-743

Russel SFS, Yonge SM. 1970. Advances in Marine Biology, Vol 8. Academic Press Inc., New York.

Setiawan H. 2013. Status ekologi hutan mangrove pada berbagai tingkat ketebalan. Jurnal Penelitian Kehutanan Wallacea 2 (2): 104-120.

Shao KT, Chen CY. 2003. Atlas of Fishes. Yuan-Liou Publishing Company, Taiwan.

Sichum S, Tantichodok P, Jutagate T. 2013. Diversity and assemblage patterns of juvenile and small sized fishes in the nearshore habitats of the Gulf of Thailand. Raffles Bull Zool 61 (2): 795-809.

Stoner AW. 1986. Community structure of the demersal fish species of Laguna Joyuda, Puerto Rico. Estuaries 9: 142-152.
Thayer GW, Colby DR, Hettler WF. 1987. Utilization of the Red Mangrove prop root habitat by fishes in South Florida. Mar Ecol Prog Ser 35: 25-38

Tse P, Nip THM, Wong CK. 2008. Nursery function of mangrove: A comparison with mudflat in terms of fish species composition and fish diet. Estuar Coast Shelf Sci 80: 235-242.

Vaslet A, Phillips DL, Fance C, Feller IC, Baldwin CC. 2012. The relative importance of mangroves and seagrass beds as feeding areas for resident and transient fishes among different mangrove habitats in Florida and Belize: evidence from dietary and stable-isotope analyses. J Exp Mar Biol Ecol 434: 81-93.

Wang M, Huang Z, Shi F, Wang W. 2009. Are vegetated areas of mangroves attractive to juvenile and small fish? The case of Dongzhaigang Bay, Hainan Island, China. Estuar Coast Shelf Sci 85: 208-216. 